\title{
$>\operatorname{ta}_{\mathfrak{a}}$
}

\section{CLIMATE CHANGE MITIGATION AND HUMAN FLOURISHING}

RECOVERING TELEOLOGY, AVOIDING TYRANNY

by Paul Tyson 


\title{
méta Working Papers
}

\author{
Editor: Dr Sotiris Mitralexis \\ Assistant Editor: Kostas Raptis
}

\author{
Advisory Committee \\ Dr Antara Haldar, University of Cambridge \\ Dr Kostas Kanellopoulos, University of Crete \\ Dr Athina Karatzogianni, University of Leicester
}

Dr Vasilis Kostakis, Tallinn University of Technology \& Harvard University

Dr Lyndsey Stonebridge, University of Birmingham

Dr Nicolas Theocarakis, University of Athens

Dr Paul Tyson, University of Queensland

Dr Yanis Varoufakis, University of Athens

Dr Sissy Velissariou, University of Athens

Dr Mari Velonaki, University of New South Wales

The Centre for Postcapitalist Civilisation's working papers series, méta Working Papers, publishes peer-reviewed interdisciplinary research that explicitly or implicitly explores aspects of our liminal times, of our transition towards postcapitalist futures - be they dystopian or utopian, or anything in between. We are particularly interested in the exposure of academic works-in-progress to an audience of postcapitalism-oriented thinkers.

méta Working Papers welcomes solicited and unsolicited papers in English, Greek, or preferably both, on aspects of the nascent postcapitalist era and follows a singleblind peer review process. The Papers are on-line open-access publications under the Creative Commons CC BY-NC-ND license. An indicative word count would be around 3.500-7.000 words. Our non-binding suggestion for references is the Chicago Style system, either notes+bibliography or author-date. Submissions must include an abstract. Authors must include a biographical note of 60-100 words. The editorial team maintains final discretion over publication of all content. Publication does not entail an endorsement of mźta Working Papers' contents, which reflect the views only of the authors, and méta cannot be held responsible for any use which may be made of the information contained therein.

Correspondence and submission: postcapitalism.centre@gmail.com, cc'ing s.mitralexis@metacpc.org, with 'méta Working Papers Submission' on the subject line. 


\title{
Climate Change Mitigation and Human Flourishing:
}

Recovering Teleology, Avoiding Tyranny

\author{
Paul Tyson
}

\begin{abstract}
It is most unlikely that adjusting to a 1.5 to 2 degree hotter world is possible within the prevailing political and economic norms of our times. In our post-capitalist times we need to modify modern technological market "liberalism" (which has become, actually, techno-feudalism). If we do not modify our present norms, the collapse of the natural means of power and privilege native to our present world order makes it almost inevitable that democratic liberalism will devolve further into a distinctly anti-liberal species of techno-tyranny. To avoid such a dystopian future, this paper explores how we might re-imagine our global politico-economic norms without embracing techno-tyranny. The argument put forward is that modern liberalism makes the means of personal wealth accumulation and private freedom, the end of public life. This confusion of means with ends implies, ironically, that if our means become unviable, we have no way of aiming at valuable human ends by different means. We have a culturally assumed faulty teleology in political economics and in our philosophy of technology. A revised form of Aristotle's teleology is proposed whereby an understanding of common human flourishing defines human ends, and where a range of new means could then be pursued to achieve that end, respecting the natural limitations on means that are now upon us.
\end{abstract}

Dr Paul Tyson is an interdisciplinary scholar working across sociology, theology and philosophy. He is an honorary senior fellow at the Institute for Advanced Studies in the Humanities at the University of Queensland, Australia, and a member of méta's Advisory Board. His most recent book is Theology and Climate Change (Routledge, 2021).

"The author of this paper wishes to acknowledge, with thanks, that this working paper is the result of many discussions with Jose Garibaldi and other members of the Energeia Network. 
If we are to sensibly and humanely adjust to living in a hotter globe, and if we are to take the necessary action now to prevent global warming from going higher than 1.5, or at the very most 2 degrees, we will need to make significant changes to the way we live. Political and economic normality, on a global scale, will need to change. This is not as shocking a statement as it sounds. The prevailing liberal democratic norms of the West have only been with us since the nineteenth century and have continually changed in the course of their short history, and likewise, the norms of global trade, geopolitical power and international finance that have been with us since the 1980s, also show constant dynamism. Yanis Varoufakis persuasively argues that capitalism as conceived of by the classical and neoclassical theorists is no longer with us; we live in post-capitalist times. ${ }^{1}$ Yet we are still in civilizational bondage to the doctrines of a capitalism that no longer exists. As long as we cannot think outside of a defunct theory that does not describe the world as we actually experience it, we will be unable to think up genuinely adequate ways of understanding and responding to our actual situation. And the reality is, the natural resource exploitation norms of both capitalism and its post-capitalist heir (what Varoufakis describes as techno-feudalism²), have caused climate change. We need a different theory (vision) to underpin a different praxis and a better political economics than currently prevails.

\footnotetext{
${ }^{1}$ Yanis Varoufakis et al., Is Capitalism Broken?, London: Oneworld Publication, 2020.

${ }^{2}$ Yanis Varoufakis, "Techno-Feudalism is Taking Over" Project Syndicate Op-ed, 28 June 2021, https://www.yanisvaroufakis.eu/2021/07/05/techno-feudalism-istaking-over-project-syndicate-op-ed/
} 


\section{Paul Tyson: Climate Change Mitigation and Human Flourishing}

Two serious problems embedded in defunct theory that face us as we look forward are teleology and tyranny.

Teleology is concerned with the meaningful purpose of things, and - as far as people are concerned - with trying to understand what a good life is. In traditional teleological terms, 'good' here means a communally situated life of human flourishing and fulfilment. For reasons we shall unpack below, we can't seem to do genuine teleology anymore. Trying to adjust the conditions and means of life that are now failing us, so that we can pursue a common good of genuine human flourishing, under different conditions, seems outside of our conceptual tool kit. For enhancing the conditions of personal freedom and personal wealth accumulation, and securing the means of power, has become our purpose, such that we cannot sensibly isolate means/conditions form ends/purposes anymore. For this reason, if our present means of obtaining freedom, power and wealth are failing us, we seem unable to drop those means and pursue valuable ends by other means.

The problem that directly arises from our collective inability to separate means from ends is tyranny. If the conditions of our present structures and norms of wealth and power come under threat (which is already happening with global environmental stress) and if the guiding first 'purpose' of our present world order is simply to preserve the conditions upon which our present structures of wealth and power depend, then the majority of people will increasingly be treated in very heavy handed ways so as to preserve the wealth and power of the status quo. The future may well be controlled by a sort of environmental authoritarian policing entity - not run by Greenies, but run by Money and Power- with stronger legal, military and technological walls separating the wealthy and powerful from the poor and powerless than 


\section{Paul Tyson: Climate Change Mitigation and Human Flourishing}

we can presently imagine. That is, an inability to radically adjust the means of life that our present world order is dependent on, will naturally devolve towards increasingly autocratic and oppressive minority rule (tyranny) as the means themselves erode.

In this short catalyst paper, I shall have a go at thinking about how we might recover genuine teleology and avoid tyranny as we head towards a 1.5 to 2 degree hotter future.

\section{Why Liberal 'Teleology' leads to Autocratic Tyranny}

Teleology is the science of purpose, famously developed in the West by Aristotle a very long time ago. When the modern West threw out Aristotle's natural philosophy and embraced what we now call the scientific revolution, we dropped the complex science of teleology altogether (or so we thought). Which is to say that modern scientific and technological thinking does not think that purpose is a natural feature of the world. 'Purpose' is now thought of as an entirely human construction. Natural reality itself has no purpose, no meaning, no value - these are all cultural glosses imaginatively projected onto the world by us - even if some of nature's mechanisms look purposive. In evolutionary biology, for example, all organisms 'succeed' because they survive. But survival is not a purpose, it is not an end (all organisms die, all species become extinct) it is just a mechanism, a means, of biological adaptation. This point is very important when we think about 
climate change: survival is in no manner equivalent with meaningful and purposive flourishing. ${ }^{3}$

In the late medieval universities of Western Christendom, Aristotle's natural philosophy was a complex amalgam of theology, metaphysics, ethics, science, mathematics and logic. Sympathetic mystical properties in the natural world - alchemical, magical, and astrological ideas, etc. - were by no means off limits to the natural philosopher. The way in which esoteric and religious doctrines, moral values, intrinsic meanings, speculative metaphysics, logic and observation were all tangled up in the medieval visions of nature was seen - by the fathers of modern science - as a hopeless mess. University Aristotelianism got in the way of simply observing the objective facts and gaining utilitarian power over nature through experimental knowledge. Useful and factual knowledge was the goal of the new learning.

So teleology was abandoned. Knowledge - of observable facts and demonstrably valid theories - pushed purpose, value, theology and transcendence out of science and technology, to the great improvement of our factual knowledge and technological power. But modern knowledge, as power ${ }^{4}$ - uncoupled from wisdom, revelation, moral truths and the purposive signatures of genuine human flourishing is the central cause of our present global environmental crisis. ${ }^{5}$

\footnotetext{
${ }^{3}$ Of course, should we all die, then no-one will flourish. Survival is a means that can serve the end of flourishing. But survival itself has no necessary relationship with flourishing.

${ }^{4}$ John Henry, Knowledge is Power. How Magic, the Government and Apocalyptic Vision Helped Francis Bacon to Create Modern Science, London: Icon, 2003.

${ }^{5}$ Paul Tyson, Theology and Climate Change, London: Routledge, 2021.
} 
Even so - in the high age of modernity - we got on without natural and metaphysical purpose pretty well, and we developed a distinctive form of government and economics around this absence of purpose. Secularized liberalism usually entails the idea that there is no transcendently defined common good, and there is no natural or metaphysical definition of true human meaning, but if individuals have access to factual knowledge and financial power, they can decide to pursue whatever personal purpose they see fit. ${ }^{6}$ As the Book of Judges puts it, everyone can do "whatever seems right in their own eyes."7 Freedom is having no-one tell you what you ought to find meaningful and fulfilling, or even right or wrong, but having enough private means to pursue whatever you alone decide gives your life purpose and meaning. Liberal politics and free market economics is premised on there being no 'true' definition of human flourishing, and no 'common good' that all individuals should morally and/or religiously be committed to. Rather, securing the means to pursue your own purposive commitments is now the only common good.

Setting our political and economic world up so that we can all pursue each individual's choice of meaning, so that each constructed vision of morality and every simply preferred purpose can be pursued, has a problem. If everyone is their own highest authority as regards morals and meanings, and if everyone is essentially self-concerned in the pursuit of their own freedoms and fulfilment, if markets and governments are inherently competitive and if power acquisition is a basic ambition of all, then there is no natural peace. The state of

\footnotetext{
${ }^{6}$ Milton and Rose Friedman, Free to Choose, New York: Harcourt Brace Jovanovich, 1980.

${ }^{7}$ Judges 17:6
} 
nature - as Hobbes understands it - is the war of all against all. ${ }^{8}$ The modern liberal answer to this problem is the legal fiction of a social contract between self-interested individuals and the modern state, such that the state takes on a monopoly of violence. Law defines a certain set of publically mandated rules of behaviour (whether they are right or wrong, fair or biased, is of no matter to the Hobbesian tradition) which the state impartially upholds, with supreme violence. Thus a minimally imposed procedural order, backed up by irresistible force, keeps self-interested, competitive, morality and meaning constructing individuals from simply killing and unscrupulously exploiting each other. Thus is personal freedom and public peace made compatible, without a moral or religious or metaphysical teleology. We would like to think that now - in the enlightened adulthood of humanity - we do not need any shared vision of human flourishing which structures any essentially moral and religious idea of the Common Good. Indeed, freedom from such a Common Good, and freedom for the individual from any collectively imposed doctrinal, moral and doxological norms, is what we find so wonderful about our life-world. This vision of freedom itself is what makes us modern. The cosmogenic mythology of the modern age is overtly defined by the casting off of the Common Good impositions of purpose and meaning on the individual from the superstitious and meddling Church in the bad old times of medieval Christendom.

\footnotetext{
${ }^{8}$ Thomas Hobbes, Leviathan, chapter 13 "Of the natural condition of mankind as concerning their felicity and misery", London: J.M. Dent \& Sons LTD, 1914, 64. "Hereby it is manifest, that during the time men live without a common Power to keep them all in awe, they are in that condition which is called Warre; and such a warre, as is of everyman, against every man."
} 


\section{Paul Tyson: Climate Change Mitigation and Human Flourishing}

But we are not as free of teleology as we might imagine. Modern liberalism has turned the means of personal freedom and the upholding of state sanctioned order into the end of human society as such. So actually, we did not dispense with teleology when we dispensed with Aristotle and the Church. We now pursue the common 'end' of a society in which all have the means of pursuing whatever values and purposes each individual decides for herself, and this 'end' is guaranteed by the amoral and impartially regulating, violent secular state. We are now deeply committed to this view of a strictly procedural definition of the purpose of human life. But this view of purpose is profoundly tied to a system of economic and natural exploitation means, which are integral with the modern scientific and technological age, and mastery of those means gives power and status in the modern consumer life-world.

The distinctive features of modern (anti)teleology is now an enormous problem if we must change our means of living with nature. If we cannot separate the personal pursuit of wealth and power (instrumental means) from common human flourishing (an intrinsically valuable end), then those who have power will simply preserve that power at the cost of those without power as the conditions of human life come under increasing environmental stress. Thus does Liberalism lead naturally to Tyranny.

When we think of the realm of the common good as inherently procedural, and as defined by entirely material and economic categories of wealth, power and opportunity this - as the post-war $20^{\text {th }}$ century illustrated - can produce a reasonably happy liberal consumer 
society. ${ }^{9}$ Yet the liberal consumer vision of the good life combined with exponential human population growth and an ideology of unending economic growth, puts increasing pressure on the natural balances of the planet. Clearing land, growing beef, harnessing the natural resources of the world to feed economic growth and the pursuit of financial profit, burning huge quantities of fossil fuel, unrestricted global trade operating at ever accelerating speed and levels of flow, is no longer naturally sustainable. This order is not viable into the future. As limits and tipping points are reached and exceeded, then discontent in those who are made intrinsically vulnerable and the sense of threatened entitlement of those fearfully holding onto power and privilege will generate an appointment with global human catastrophe. But this unwinding of the present world order will be executed

\footnotetext{
${ }^{9}$ Some nuance is important here. In, for example, Australia, the post-war boom 1949 to 1971 - was a period of sustained income and living standard increase for all categories of Australians, and the relative disparity between the rich and the poor was low. The 1970s was a period of stagflation chaos with the unravelling of the Bretton Woods system, which resolved itself into neoliberal globalization in the 1980s. Since that time the disparity between the rich and the poor has raised dramatically, with economic growth and prosperity increasingly reaching only the already rich and privileged, and with the collapse of manufacturing and agriculture as employment sectors after globalization leaving many Australians in inherently insecure and unsatisfying service sector work, and in low income personal debt traps. The 'two speed economy' is not reflected in aggregate GDP growth indicators, which largely favour the top gear at the expense of the bottom gear. See Michael Pusey, The Experience of Middle Australia, Cambridge: Cambridge University Press, 2003. This text is now almost 20 years old and is historically interesting in that it is published roughly in the middle of the neoliberal experiment. The trends in blue collar income stagnation and debt traps and tenuous, low-paid, unsatisfying work for the bottom gear described by Pusey have only increased and to the point where its sustainability cannot last for much longer; hence the rise of more extreme populist figures and scapegoating, harnessing electoral resentment in Australian politics.
} 


\section{Paul Tyson: Climate Change Mitigation and Human Flourishing}

with tools of surveillance and financial power, and tools of military destruction, the like of which we have never seen before. As conditions worsen and 'states of emergency' become normalized, governments have less accountability to electorates and police powers become increased to provide us with "safety" in uncertain times. We are cooking up an age of tyrants backed by elite power interests using staggeringly invasive and deadly technologies.

How can we avoid not only catastrophic environmental destruction but an age of unprecedented techno-political oppression?

One possible alternative to just letting modern liberalism destroy itself and taking down human civilization as we know it in the process, is trying to transition out of modern liberalism, without heading into Hobbesian tyranny, by recovering teleology. As mentioned, if we can isolate the means of flourishing from the ends of flourishing, then we can think about different means of securing the ends we are aiming for. If we can only associate one type of means (technologies of natural dominance) with the end of human flourishing (liberal consumer society), then we are doomed. Let us then think about how we might recover a genuinely teleological teleology in our times.

\section{Recovering teleology}

To start with, we need to know why we modernists have such as strong aversion to teleology, even though - as pointed out above - we still actually have a common (anti)teleology, which is actively opposed to any essential concept of human flourishing. That is, our post-Kantian anti-teleology is a strictly rationalist, procedural, materialist, and instrumental concept of human flourishing that has no concept of 
genuine transcendence or substantive qualitative and essential purposes.

Immanuel Kant is the most significant philosopher of modernity. The unsolvable problem for eighteenth century rationalists was the circularity and abstractness of logic (a priori pure reason cannot connect with the world of contingent material facts), and the unsolvable problem for eighteenth century empiricists was the problem of induction (if you only know what you observe a posteriori, then you cannot be sure that because something happened in the past, it will happen the same way in the future). Kant solved both of these problems in one ingenious move. Kant made the centre of philosophical meaning the human mind, rather than reality itself. That is, the world of phenomena is the world we know, and in contrast, the world as it is in itself (noumena) is outside of our knowledge. In our experience of phenomena both the a priori world of logical structures and the a posteriori world of sensible observations combine in our mind to produce our understanding of the world. The world itself - as independent of our mind - is literally beyond experience, so the world we experience is, for us, the world. So reason and sensation are unified as functions of our own mind, rather than as tools that provide certain knowledge of how reality itself (noumena) is. This 'solves' all the metaphysical problems of modern philosophy by making metaphysics (reasoning about noumena) itself a non-issue. That is, Kant replaces noumenal 'transcendence' with the phenomenological 'transcendental'.

To Kant 'the transcendental' is the rational and interpretive structures of how we experience sensory phenomena. Modern philosophy after Kant is only interested in mind-defined (and this is our mind, not the mind of God) experience, and mind-defined constructions of 
meaning and value that have rational and empirical integrity with how our mind's structure experience. Aristotle's assumption that meaning, morality and purpose are actually in nature, and have a genuinely transcendent final origin (the Divine Mind) such that qualities are real features of reality, not just human cultural glosses, is now decisively abandoned by recognizably modern thought. So a liberal pluralist self-defined understanding of culturally situated value and meaning, as functions of our own individual minds, strikes us modernists as obviously correct. The idea that value, meaning and purpose exists in reality itself (independent of our minds) and has a genuinely transcendent origin (i.e., that quality and meaning really are inherently different categories of reality to quantities and facts), makes no sense to us now. But... what if Kant's ingenious move is an intellectual slight of hand, and what if Aristotle is right? What if there really is such a qualitative reality as human flourishing, but there are different ways of securing that flourishing? (Recall, we post-Kantians tend to assume the inverse of this; we tend to assume that a certain set of material means defines human flourishing because there really is no such thing as quality and purpose in reality that gives humanity any essential and true meaning.)

Kant is wrong. There is no necessary reason why the rational and empirical structures of our knowledge of phenomena entail that the noumenal itself is unknowable. ${ }^{10}$ But it is convenient for us to accept Kant's model because this makes us the makers of our own values and purposes. That is, we become our own God. Marx makes the theological implications of the Kantian revolution in philosophy overt. Kant

\footnotetext{
${ }^{10}$ William Desmond, The Intimate Strangeness of Being. Metaphysics after Dialectic, Washington D.C.: Catholic University of America, 2012, xiii - xxi.
} 
explains that he has effected a Copernican revolution in philosophy, where our knowledge of reality now revolves around the epistemic structures and constructions of the human mind, rather than the mind revolving around reality. ${ }^{11}$ Marx explains that once Man is the centre of all knowledge, and all meaning and purpose, then God is obsolete and Man worships himself as the final source of all value, meaning and power. ${ }^{12}$

Contra Kant, there are long and intellectually serious traditions of thought and experience where the noumenal is actively engaged in

\footnotetext{
${ }^{11}$ Immanuel Kant, Critique of Pure Reason, London: Everyman, 1993, 15 [preface to the second edition, Bxvi, 1787]. "It has hitherto been assumed that our knowledge must conform to the objects; but all attempts to ascertain anything about these objects a priori, by means of concepts, and thus to extend the range of our knowledge, have been rendered abortive by this assumption. Let us then make the experiment whether we may not be more successful in metaphysics, if we assume that the objects must conform to our knowledge... We propose to do just what Copernicus did in attempting to explain celestial movements... If the intuition must conform to the nature of objects, I do not see how we can know anything about that nature a priori. If, on the other hand, the object (qua subject of the senses) conforms to the nature of our faculty of intuition, I can then easily conceive the possibility of such an a priori knowledge.

${ }^{12}$ Karl Marx, "Contribution to the Critique of Hegel's Philosophy of Right: Introduction" 1844, in Robert C. Tucker, The Marx-Engels Reader, $2^{\text {nd }}$ edition, New York: Norton, 1978, 54. Here Marx is exalting in the work of Ludwig Feuerbach [The Essence of Christianity]. The impact of first Kant and then Hegel on the German thought world of the early to mid-nineteenth century can hardly be over-estimated. Feuerbach's embedding in that thought world is intimately entailed in his view that Christianity seeks to create God in the image of man. Again, the centre and periphery of the traditional theological perspective has been inverted in a 'Copernican' move. In light of that re-definition Marx comments:

"The criticism of religion disillusions man so that he will think, act and fashion his reality as a man who has lost his illusions and regained his reason; so that he will revolve about himself as his own true sun. Religion is only the illusory sun about which man revolves so long as he does not revolve about himself."
} 


\section{Paul Tyson: Climate Change Mitigation and Human Flourishing}

various radiances of self disclosure to the human mind. ${ }^{13}$ Further, the idea that there are no values or purposes in nature, and these are only human constructions of culture, is an abstract logical possibility, but such a position is very hard to believe in practice. At least, it is a learnt skill rather than a natural disposition to see modern phenomenological reductionism is anything other than an intellectual parlour game. For no-one who really loves someone actually believes (in existential practise) that the source of the value of the beloved is simply one's own mind. It is the person who is intrinsically, essentially valuable; it is not my perceiving of the person that makes them valuable. This is not to deny the ego-centric, quantitative, subjective and cultural conditions in which we experience value; physical triggers and needs are intimately entailed in most forms of inter-personal attachment, and how we understand value, meaning and purpose is always subjectively and culturally situated. But reducing value itself to the conditions in which we perceive value, and centring the locus of meaning in our own subjectivity, is simply not how we actually live as valuing beings.

Aristotle is, at the very least, probably right about the real existence of essential value in the natural world, and he is probably right about some genuinely transcendent cosmic framework of meaning that is the source of value itself. At the least, it is natural to assume he is right given our actual experience of value and purpose as inherently beyond our own construction. Our normal sense of real value is exactly not

\footnotetext{
${ }^{13}$ Broadly speaking, this is the Classical tradition of Plato and Aristotle. For a powerful contemporary expression of that tradition, see again William Desmond, The Intimate Strangeness of Being. The so-called post-metaphysical Kantian collapse of metaphysics into phenomenology is by no means as decisively achieved as both modern and postmodern philosophers in the shadow of Kant and Hegel would like us to believe.
} 
narcissistic, but it is ego-extrinsic, and as regards the idea that the cosmos itself is simply a conglomerate of material stuff without any meaning or purpose, this is hard to genuinely believe.

As serious religion has declined in the modern West after the secularization of the $19^{\text {th }}$ century ${ }^{14}$ this has not produced an enlighten atheist civilization of high Marxist spirituality; it has rather produced a wide vista of personally constructed private superstitions - consumer spiritualities. It seems that G.K. Chesterton was correct in observing that "the first effect of not believing in God is to believe in anything." 15 Lawrence Krauss may think that the blank hermeneutic slate of a meaningless cosmos is a liberating and joyous - as well as true - outlook. Indeed, our modern commitment to meaning constructivism gives life-world credibility to this doxology of the Great Nihil; but most people still need to construct some personal rituals of liturgical meaning (shopping is the central liturgy of consumerism), ${ }^{16}$ and fashion objects of emotional veneration (such as horrendously spoilt house pets) as small carriers of cosmic significance which they at least practically pretend to be of real significance beyond their own making. For

\footnotetext{
${ }^{14}$ See two excellent books of Gifford Lectures on this fascinating topic: Owen Chadwick, The Secularization of the European Mind in the $19^{\text {th }}$ Century, Cambridge: Cambridge University Press, 1975; Charles Taylor, A Secular Age, Cambridge MA: Harvard University Press, 2007.

${ }^{15}$ According to Oxford Essential Quotations (4 ${ }^{\text {th }}$ edition, ed. Susan Ratcliff, Oxford: Oxford University Press, 2016, G.K. Chesterton entry 53; https://www.oxfordreference.com/view/10.1093/acref/9780191826719.001.0001/q-oro-ed4-00002890), this quote is attributed to G.K. Chesterton by Émile Cammaerts in his book on Chesterton, The Laughing Prophet, London: Methuen \& CO., 1937.

${ }^{16}$ William Cavanaugh, Being Consumed, Grand Rapids: Eerdmans, 2008; James K.A. Smith, Desiring the Kingdom, Grand Rapids: BakerAcademic, 2009; Daniel M. Bell Jr., The Economy of Desire, Ada MI: Baker, 2012; Chanon Ross, Gifts Glittering and Poisoned, Oregon: Cascade, 2014.
} 
can we actually live personally meaningful lives in a meaningless cosmos? The existential difficulties of consistent cosmic absurdism would suggest that only a very elite minority will ever even aspire to this lofty absurdist spirituality as an actual practice of life (as distinct from a mere solipsistic doctrine of constructivist convenience). ${ }^{17}$ On the other hand, it seems unlikely that serious religion will, after all, simply die out. ${ }^{18}$ Between religion and absurdism, an anarchic montage of existentially convenient, morally relativistic, and constructed superstitions, glorified under the banner of personal authenticity, ${ }^{19}$ now abounds in modern consumer societies.

So let us run with Aristotle's pre-Kantian outlook on the reality of value and meaning in and beyond the natural world. Let us re-invert the revolutionary Copernican assumption of $\mathrm{Kant}^{20}$ and assume that purpose and value exist in reality itself (rather than just in our mind), and that the nature of purpose and value cannot be defined in

\footnotetext{
${ }^{17}$ See G.K Chesterton, Manalive, New York: Dover, 2003, for a concerted imaginative attempt at seeking to understand what existential authenticity consistent with the doctrine of cosmic absurdism might result in. Chesterton's point is that actually, this doctrine cannot be lived.

${ }^{18}$ See Peter L. Berger (ed.), The Desecularization of the World, Grand Rapids MI: Eerdmans, 1999. Berger, as one of the leading sociologists of the $20^{\text {th }}$ century, became one of the key thinkers in criticizing the now discredited 'secularization thesis' which - contrary to the sociological evidence - theorizes that a post-religious nonmetaphysical materialism will inevitably replace religion as societies modernize. ${ }^{19}$ Charles Taylor, The Ethics of Authenticity, Cambridge MI: Harvard University Press, 2018.

${ }^{20}$ Ironically, Kant makes metaphysical reality 'geo-centric' and 'anthropocentric' if we are thinking in cosmological categories. The Copernican analogy itself, in the context of Kant's epistemology, is disingenuous. Indeed, Copernicus thought that the sun, as the Platonic symbol of God, made not only good mathematical sense in relation to our theorizing about the observable cosmos, but good theological sense as well.
} 


\section{Paul Tyson: Climate Change Mitigation and Human Flourishing}

reductively quantitative or reductively mathematical categories. Which is to say that qualities and meanings are real, but in a different way to how quantities and facts are real, and that the reality we experience has both quantitative and qualitative attributes that remain integral but irreducible to each other. ${ }^{21}$ Or we could say that the genuinely transcendent is experienced by us - normally - in the immanent world of our daily lives. The child smiles and we are spiritually touched, the sun sets and we are awed and amazed, the oceans surge and the forests live, with a power and life that is not our own, the musician performs and we are transported... we know not where; and these tantalizing communications from a qualitative and purposive noumenal realm are not simply 'for us'. Yet in these communications we are touched by a beauty and grandeur that in some manner genuinely transcends our own phenomenological consciousness. The noumenal is there and it speaks to us, even if we can never master it in the same way that we master the reasonings of our own minds, the factual analysis of our own knowledge, or the instrumental power over the material conditions in which we live. Which is to say that the categories of proof and use are certainly adequate to the realm of maths and science, but they are not adequate to the realm of meaning and purpose. Yet just because we can't have proof and instrumental mastery in relation to meaning and purpose, does not mean that the reality of meaning and purpose is speculative moonshine, and it does not mean that we simply make meaning and purpose up.

The purpose of human life, as Aristotle sees it, is not survival, but flourishing. To understand human flourishing one must study - both

\footnotetext{
${ }^{21}$ Paul Tyson, Seven Brief Lessons on Magic, Oregon: Cascade, 2019.
} 
'scientifically' and metaphysically - what naturally gives people fulfilment; that is, one must look to see what the essential nature of being human is, and how that nature realises its natural inclinations, and what conditions are necessary for that fulfilment.

\section{Updated Aristotelian teleology and climate change mitigation}

Aristotle believes the distinctive features of being human are language, reasoning and political community. That is, humans are speaking, reasoning, political animals. We are also eating, drinking, procreating, fighting and shelter making animals, but those attributes are shared with just about every other animal and are not what makes us distinctly human. In addition, we are fabricating and trading animals, but Aristotle sees these attributes as concerned with the means rather than the ends of human fulfilment; they are peripheral to teleological reasoning about the good life.

There is a notable lacunae in Aristotle's thinking that we may be well equipped to fill. Aristotle has no concept of universal human rights premised on the notion of an intrinsic human dignity. Notably, to Aristotle, some classes of people were sub-human - slaves, women, children, commoners, foreigners. Only the aristocrat citizen has the opportunity to become fully human in Aristotle's thinking. Another aspect of his thinking that seems like a lacuna, but isn't, concerns religion. What we now call religion was so integral to Greek society that Aristotle did not consciously think of humans as worshipping animals; but centres of common worth (worth-ship) worthy of highest and sacrificial devotion are integral with Aristotle's understanding of our political natures, even if the way Aristotle describes these centres are not 
identifiable as 'religious' in the modern Western sense of that word. We will return to the second point below, as it is the Highest Good that is the spiritual centre of the polis to Aristotle, and thinking in those categories of worship is still - I shall argue - of vital importance to any political community. More on that shortly. But regarding an essential and genuinely universal understanding of the human condition, let us work with the notion that genuine respect for inalienable and intrinsic human dignity - the various UN conventions around universal human rights are suitable for this purpose - can be added to the essentially human characteristics that define Aristotle's vision of human flourishing.

If we were to translate a contemporary Aristotelian teleology of humanity into the context of the climate change mitigation challenge ahead of us, this would enable us to separate means from ends, and this would enable us to work on heavily re-formulating economic, natural exploitation and national and international political means, without sacrificing the desired human ends. As argued for above, if we cannot isolate means from ends, this will result in the existing means being preserved for a shrinking minority of super powerful individu$\mathrm{als}^{22}$ at the horrendous cost of human ends (tyranny and the violation of intrinsic human dignity) for humanity as a whole. Equally, if we cannot radically re-think means (because we confuse them with ends) the global environment will continue to be degraded until climate disaster is unstoppably catastrophic.

\footnotetext{
${ }^{22}$ Susan George, Shadow Sovereigns. How Global Corporations are Seizing Power, Oxford: Polity Press, 2015.
} 
In political communities - so Aristotle maintains - might does not make right, rather reasoned persuasion with a view to the good of the community as a whole is the basis on which political authority is exercised as community endorsed power. Citizens are thus equal as reasoning, speech endowed beings, concerned with the common good as defined by high metaphysical categories - like justice. Here, sub-political categories of power - wealth and force of arms - are excluded from the process of attempting to establish a good polis in which fulfilled humans can live.

The minute one thinks about politics as a means of pursuing human fulfilment in Aristotle's terms, it becomes obvious that what we now typically call politics is more about sub-political power - wealth and sheer enforcement power - than it is about politics. Either that or government reduces to civic plumbing (though note, the proper control of private and public wealth and power, and due diligence in the running of mundane public service provisions and sensible law making, are important civil administration concerns). But the means of public debate are now increasingly controlled by social media platforms that are inherently profit driven, and in Aristotle's sense, antipolitical. That is, politics is about reasoned and free debate among equals for the common good, it is not about the relative advantage of financial power and sectional (and self) interest, which social media as a tool of "surveillance capitalism" really is about. ${ }^{23}$

\footnotetext{
${ }^{23}$ Shoshana Zuboff, The Age of Surveillance Capitalism, London: Profile Books, 2019; Jaron Lanier, Ten Arguments for Deleting your Social Media Accounts Right Now, London: The Bodley Head, 2018; Susan Greenfield, Mind Change, London: Random House, 2014.
} 


\section{Paul Tyson: Climate Change Mitigation and Human Flourishing}

When thinking about climate change mitigation, the Australian government's new plan (as of October 2021) to swing from climate change inaction to climate change mitigation is instructive. This swing is not being produced either by science or (in Aristotle's terms) by politics; it is being produced by economics. When the Trump administration was in power in the USA the Australian government had no interest in doing anything genuinely serious about climate change mitigation, and only recognized climate change as some sort of a problem (the causes of which remained unknown to our policy experts in government) in the aftermath of the accurately forecast devastating bush-fire season of 2019-20. The change of heart leading up to the 2021 Glasgow summit is because the US has changed direction, and now the Australian government does not want to be left out of the new economic boom area of non-carbon burning technologies. Essentially, the only logic driving policy is sub-political and economic; it is not inherently interested in climate science and it is not inherently interested in the political participation of citizens and a common desire to define the good life as the end of what power is set up to serve. Rather, "politics" is still all about effectively delivering the economic means of upholding the present liberal order. Securing the means of self and sectional economic interest advancement remains the only 'common good'.

As we have seen first in Australia's border security games this century, universal human rights as expressed in the Geneva Convention for asylum seekers have been ignored, just as the threat of covid has promoted heavy handed and invasive public control measures and 
population surveillance. ${ }^{24}$ Which is to say that the link between a liberal ideology and the state's monopoly on physical power is becoming increasingly overt in Australia. Australia may well swing from policy that totally ignores climate change mitigation, to policy that enforced climate change mitigation action in a draconian 'state of emergency' manner. In both cases, the dignity of the people as genuinely political decision makers is ignored so that government can mandate and impose both safety and prosperity on the nation, in the terms of both liberal economic ideology and increasingly authoritarian executive power. If there is no means of isolating political ends from economic and technological means, if there is no ability to think about the common good in terms of substantive commitments to the values of human flourishing, then liberalism will morph into tyranny as night follows day.

This brings us back to worship. In Australia in recent decades, militaristic nationalism has taken a strong upsurge. ${ }^{25}$ One of the key collective centres of value that seems to binds us self-interested consumers together, is national pride. Our soldiers - who are prepared to kill and die for our nation - have put something ahead of their own selfinterest, for the common good. So we find there are three pillars of the common good in contemporary Australian life: safety, prosperity and national pride. We forge a collective unity by: keep invading "illegal

\footnotetext{
${ }^{24}$ This is not a criticism of the use of emergency powers to address a natural disaster. But 'lock us up', 'lock them out' and 'surveillance apps for public movement' as the primary modes of emergency response have been achievable in Australia - due to its isolation and water bounded location - in ways that are not practically achievable in many other locations.

${ }^{25}$ Marilyn Lake and Henry Reynolds, What's Wrong with ANZAC? The Militarization of Australian History, Sydney: New South, 2010.
} 
immigrant" out (safety); by government policies that heavily support the mining sector (prosperity), and; by a strong military (and a strong squad of Olympic athletes) who serve their country and are prepared to sacrifice their personal interests for the glory and protection of the nation (national pride). This is our civic religion in Australia. But does this religion display a genuine vision of the highest good for the common interest, tied to genuinely transcendent and real values (pious worship), or are these constructed values that simply dress up self-interest and a fixation with grasping at the means of instrumental power (idolatry)?

Probably, as would be the case in every nation, piety and idolatry are mingled in Australian civic religion. But an unfortunately well illustrated principle (think of Nazi Germany) is that conditions of insecurity tend to promote idolatry in civic religion, rather than public interested piety. And we are facing insecure and volatile times. For this reason, Australians should be particularly concerned that the horizon of common meaning guiding the sense of collective Australian identity is genuinely defined by high transcendent truths. Piety in civic religion is not collective self-worship, it is not a function of merely constructed values and purposes. A nation is justly great when the common values and energies of the people serve truths of principle and virtue higher than mere collective self-interest and collective self-aggrandizement.

As regards the environment, does scientific expertise, suitably autonomous from (sub)political interference, get to lead policy in the areas of sustainable farming, land management, bush-fire mitigation, renewable energy and city planning, or are such knowledge experts inherently tenuous and secondary to the (anti)political needs of 
government agendas? The systematic degradation of Australia's peek scientific body (the CSIRO) over the past two decades would suggest that knowledge and common good technology have been radically debased to self-interested policy agendas that serve existing powerful sectional interests who in turn manipulate the electorate.

As regards the human ends of Australian society at large, is there any vision of human flourishing tied to high notions of justice and goodness alive in our public discourse? The language of politics was radically re-defined in the 1980 s away from political ideals and towards economic and financial management, and it has remained concerned with means rather than ends ever since. ${ }^{26}$ After 40 years, the idol of instrumental economic self-interest is worshipped as a matter of habit rather than conscious choice. This accounts for our current quick change in climate change mitigation policy for purely pragmatic reasons. But where such logic drives policy, no principled commitment to good practice, for the sake of it being morally good, can be relied upon. Should the USA change emphasis in the light of geopolitical conflict with China, for example, then the preservation of power will rapidly replace our present opportunistic 'commitments' to a viable environmental future for our children as Australia simply swings in line with the USA again.

\footnotetext{
${ }^{26}$ Michael Pusey, Economic Rationalism in Canberra. A Nation Building State Changes its Mind, Cambridge: Cambridge University Press, 1991. Manfred B. Steger \& Ravi K. Roy, Neoliberalism, a very short introduction, Oxford: Oxford University Press, 2010.
} 


\section{Conclusion}

Thinking teleologically about the common good in genuinely metaphysical categories - categories of intrinsic meaning, qualitative flourishing and transcendently horizoned values - is foreign to the techno-feudalism of our post-capitalist times. This means that the norms for our public thinkers and political actors are defined by a systems logic that is mechanistic and deterministic, policies and public discourse tends to revolve around questions of means, and the "realism" of the interests of existing financial, mass persuasion, and military power are taken as unmovable givens. This is - in Aristotle's categories - a sub-political power context where collective decision making that strives to understand the genuine common good for all - as the meaning of human flourishing, a knowledge of the good life - is largely absent. I believe we are in this place because we have embraced anti-teleological liberalism, premised on the impossibility of even partially knowing metaphysical truths about the true nature of human flourishing. We prefer to allow individuals to construct their own meanings and to leave the domain of common life to purely pragmatic concerns. Yet, modern liberalism is premised on a pragmatic concept of the state as having a monopoly on violent power, which we allow it to exercise arbitrarily, because our view of the state of nature is one of inherent combat in the pursuit of one's own interests. If the conditions of liberal self-interested contentment diminish, then the arbitrary violent power of the state will come to the fore. Thus does the attempt to make any fundamental shift in the means of wealth and power get cut off by the application of 'emergency powers' where the liberty of the ordinary citizen is radically curtailed. Under such conditions, we would perhaps be wise to wonder if we really can't figure out 
what inalienable human goods we intend political power and public policy should serve, and then we need to hold to those ends in a firmly principled manner, even if it means a collective reduction in individual, sectional and national wealth and power.

\section{Works Cited}

Bell, Daniel M. Jr., The Economy of Desire, Ada MI: Baker, 2012.

Berger, Peter L. (ed.), The Desecularization of the World, Grand Rapids MI: Eerdmans, 1999.

Cammaerts, Émile. The Laughing Prophet, London: Methuen \& CO., 1937.

Cavanaugh, Being Consumed, Grand Rapids: Eerdmans, 2008.

Chadwick, Owen. The Secularization of the European Mind in the $19^{\text {th }}$ Century, Cambridge: Cambridge University Press, 1975.

Chesterton, G.K. Manalive, New York: Dover, 2003.

Desmond, William. The Intimate Strangeness of Being. Metaphysics after Dialectic, Washington D.C.: Catholic University of America, 2012.

Feuerbach, Ludwig. The Essence ofChristianity, New York: Dover, 2008.

Friedman, Milton \& Rose. Free to Choose, New York: Harcourt Brace Jovanovich, 1980.

George, Susan. Shadow Sovereigns. How Global Corporations are Seizing Power, Oxford: Polity Press, 2015.

Greenfield, Susan. Mind Change, London: Random House, 2014.

Henry, John. Knowledge is Power. How Magic, the Government and Apocalyptic Vision Helped Francis Bacon to Create Modern Science, London: Icon, 2003.

Hobbes, Thomas. Leviathan, London: J.M. Dent \& Sons LTD, 1914

Kant, Immanuel. Critique of Pure Reason, London: Everyman, 1993.

Lake, Marilyn. and Henry Reynolds, What's Wrong with ANZAC? The Militarization of Australian History, Sydney: New South, 2010.

Lanier, Jaron. Ten Arguments for Deleting your Social Media Accounts Right Now, London: The Bodley Head, 2018. 


\section{Paul Tyson: Climate Change Mitigation and Human Flourishing}

Marx, Karl. "Contribution to the Critique of Hegel's Philosophy of Right: Introduction" [1844], in Robert C. Tucker, The Marx-Engels Reader, $2^{\text {nd }}$ edition, New York: Norton, 1978, 53 - 65.

Pusey, Michael. Economic Rationalism in Canberra. A Nation Building State Changes its Mind, Cambridge: Cambridge University Press, 1991.

Pusey, Michael. The Experience of Middle Australia, Cambridge: Cambridge University Press, 2003.

Ratcliff, Susan. (ed.), Oxford Essential Quotations, $4^{\text {th }}$ edition, Oxford: Oxford University Press, 2016.

Ross, Chanon. Gifts Glittering and Poisoned, Oregon: Cascade, 2014.

Smith, James K.A. Smith, Desiring the Kingdom, Grand Rapids: BakerAcademic, 2009.

Steger, Manfred B. \& Ravi K. Roy, Neoliberalism, a very short introduction, Oxford: Oxford University Press, 2010.

Taylor, Charles. A Secular Age, Cambridge MA: Harvard University Press, 2007.

Taylor, Charles. The Ethics of Authenticity, Cambridge MI: Harvard University Press, 2018.

Tyson, Paul. Seven Brief Lessons on Magic, Oregon: Cascade, 2019.

Tyson, Paul. Theology and Climate Change, London: Routledge, 2021.

Varoufakis, Yanis. et al., Is Capitalism Broken?, London: Oneworld Publication, 2020.

Varoufakis, Yanis. "Techno-Feudalism is Taking Over" Project Syndicate Op-ed, 28 June 2021, https://www.yanisvaroufakis.eu/2021/07/05/techno-feudalism-is-taking-over-project-syndicate-op-ed/

Zuboff, Shoshana. The Age of Surveillance Capitalism, London: Profile Books, 2019. 


\section{méta Working Papers}

The Centre for Postcapitalist Civilisation's working papers series, méta Working Papers, publishes peer-reviewed interdisciplinary research that explicitly or implicitly explores aspects of our liminal times, of our transition towards postcapitalist futures - be they dystopian or utopian, or anything in between. We are particularly interested in the exposure of academic works-in-progress to an audience of postcapitalismoriented thinkers.

It has been noted that it is easier to imagine the end of the world than the end of capitalism, invoking the need for serious reflection on the end of the existing order and a transition to a postcapitalist way of life. Yet the future of the world economy is but one of the aspects of postcapitalism. After all, capitalism itself might be prima facie an economic system, but it has evolved into a comprehensive political, cultural, anthropological and international order. Postcapitalism, however it might evolve, is not merely the modification of an economic system; it will prove to be a new political, cultural, anthropological, civilisational paradigm - a new era indeed. A dystopian one, a utopian one, or anything in between. And the turbulences of the gradual transition are to be witnessed by all. The oligarchic decline of liberal democracy engenders countless variations of authoritarian tendencies; the supply chain of tributes for the global minotaur are increasingly interrupted; novel desiderata for emancipation are articulated; the chasms between megacities and provinces nurture silent, cold civil wars; the emergence of a non-Anglophone, non-Atlantic, non-liberal, non-bipartisan state as the planet's largest economy is just around the corner, overturning a twocenturies-old order; the changes in global demography and geopolitics are vertiginous; climate change is threatening our very existence. Transformations of gigantic proportions radically reshape the world before our very eyes.

With social sciences and the humanities as our main launching pad, disciplines that are of interest to the méta Working Papers series include, but are not limited to, political economy, political science and international relations, history of ideas, sociology, law, religious studies, innovation and governance, area studies, and so on - provided that the research in question is of relevance to a lato sensu postcapitalist enquiry.

méta Working Papers welcomes solicited and unsolicited papers in English, Greek, or preferably both, on aspects of the nascent postcapitalist era and follows a single-blind peer review process. The Papers are on-line open-access publications under the Creative Commons CC BY-NC-ND license. An indicative word count would be around 3.500-7.000 words. References should follow the Chicago Style system, either notes+bibliography or author-date. Submissions must include an abstract. Authors must include a biographical note of 60-100 words. The editorial team maintains final discretion over publication of all content. Publication does not entail an endorsement of méta Working Papers' contents, which reflect the views only of the authors, and mé ta cannot be held responsible for any use which may be made of the information contained therein. Correspondence and submission:

postcapitalism.centre@gmail.com, cc'ing s.mitralexis@metacpc.org, with 'méta Working Papers Submission' on the subject line. 